\title{
Optimization of Parameter Operation in Pem Fuel Cell Using Electrical Equivalent Model
}

\author{
${ }^{1}$ M. Azri, ${ }^{1}$ M H Bahrom, ${ }^{1}$ A. N.A. Mubin, ${ }^{1}$ N.H.A. Khanipah, ${ }^{1}$ Z. Tbrahim, \\ ${ }^{2}$ N.A. Rahim and ${ }^{2}$ S.R.S. Raihan \\ ${ }^{1}$ Center of Robotics and Industrial Atumation (CeRIA), Faculty of Kejuruteraan Eiektik (FKF), \\ University Teknikal Malaysia Malaysia, Hang Tuah Jaya, 76100 Durian Tunggal, Melaka, Malaysia \\ ${ }^{2}$ UMPEDAC, Level 4, Wisma R\&D (UM) University of Malaya, Kuala Lumpur, Malaysia
}

\begin{abstract}
This study presents the optimization of parameter operation in (PEMFC) Proton Exchange of Fuel cell using the electrical model and the mathematical model. The parameters of the fuel cell are hard to be determine since, the developer did not provides their parameter in details. The modelling of thermodynamic mathematical model and the electrical model is model based on a dynamic model and both is modeled using Matlab/Simulink simulation software by following the Horizon-500 specification. The analysis of the model is model based on the losses of the system. The cell temperature plays a role in affecting the value of losses in the model. The input pressure plays part in affecting the stack output of the mathematical model where it is proven that a higher pressure will produce large difference in the stack output. The efficiency for both mathematical and electrical is below $10 \%$ less compared to the specification of Horizon-500 specification thus the model parameter is verified.
\end{abstract}

Key words: Fuel cell, proton exchange membrane fuel cell, electrical model, mathematical model, specification, verified

\section{INTRODUCTION}

The fuel cell is a device that converts chemical reactions between Hydrogen $\left(\mathrm{H}_{2}\right)$ and Oxygen $\left(\mathrm{O}_{2}\right)$ into an electrical energy without any combustion. The reaction is called the oxidation reduction where the oxygen was taken from the surroundings and the hydrogen were injected into the system. The process of getting the electricity is similar to electrolysis, which is the process of separating proton and electron by using the cathode and anode. The electron will be channeled to the cathode and produce electricity while the product of the anode reaction is water $\left(\mathrm{H}_{2} \mathrm{O}\right)$.

There are six types of fuel cell that has been develop in the current technology is the Phosphoric Acid Fuel Cell (PAFC), Solid Oxide Fuel Cell (SOFC), Alkaline Fuel Cell (AFC), Direct Methanol Fuel Cell (DMFC), Molten Carbonate Fuel Cell (MCFC) and Proton Exchange Membrane Fuel Cell (PEMFC). The differences between the fuel cell is the type of electrolyte and the material used for the electrodes. The fuel cell is the answer towards the dependent renewable energy on the weather that will prevent the certain process from being completed due to the surroundings and slow in generating electricity.
The advantages of PEMFC compared to other type of fuel cell is that the construction of PEMFC is compact and it can produce a large current density by the usage of hydrogen as electrolyte and PEMFC uses solid electrolyte which has speeds up it starts up process. The properties of hydrogen which is cheap, easy to be find and powerful which has lead the PEMFC towards its production of desired power with lower working temperature. The PEMFC can operates up to $200^{\circ} \mathrm{C}$ temperature and in a normal operation it operates at $80^{\circ} \mathrm{C}$. The temperature is causes by the production of electric current where the higher amount of power produced leads to a higher amount of heat (Mann et al., 2000).

In a fuel cell modelling, there are two types of model for the fuel cell that is a steady state model and thermodynamic model. Every model has a different features and connection to fulfil the criteria of the fuel cell based on the performance of the fuel cell. Steady state is the criteria that should be considered first for modelling PEMFC. The activation losses, concentration losses and the ohmic losses are the main losses that delivered practically from the fuel cell and can be observed through the steady state model.

A dynamic model is a coupled of complex system which are solid-heat-electrochemistry that was the

Corresponding Author: M.H. Bahrom, ${ }^{1}$ Department of Power Electronics and Drives, Faculty of Electrical Engineering, Universiti Teknikal Malaysia Melaka, Melaka, Malaysia 
process of the electrochemical reaction. Understanding the dynamic electrical behavior of the fuel cell, the effect of the charge double layer capacitance who known as $V_{c}$. Charge double layer capacitance occurs during the contact between two materials that is a form of a jumping charge from one material to another. In fuel cell, the charge double layer occurs when the reaction between the electrode and the ions in the electrolyte.

The fuel cell has no resistance in generating electricity due to its flexibility towards the surrounding and an independent working environment that will enhance the generation of electricity. The only problem with fuel cells is that the technology is still new and requires high cost of maintenance. Therefore, a modelling has been carried out using simulation software which is a $\mathrm{Matlab} /$ Simulink to determine the performance of the fuel cell itself and comparing the electrical and the mathematical model results to observe the difference.

The purpose of this paper is to optimize the parameter of the PEMFC by develop a thermodynamic mathematical and electrical model of the PEMFC using simulation software program Matlab/Simulink. The simulation results for the electric model will be compared with the mathematical model to differentiate the performance between the electrical and mathematical model of the PEMFC by referring to the specification of Horizon-500.

\section{MATERIALS AND METHODS}

Equivalent dynamic circuit of pemfc: The modelling of thermodynamic mathematical model and the electrical circuit of the PEMFC is based on dynamic circuit. The presence of charge double layer capacitance and the open circuit voltage in both thermodynamic mathematical and electrical plays a role on the output of both model.

Charge double layer capacitance: Charge Double Layer capacitance $(\mathrm{CDL})$ is a phenomenon that occurs between two metal plates which the electrodes and an adjacent electrolyte. The phenomenon resulting in a jumping of charge from anode to electrode where the separation of the electron happens in the chemical reaction that is oxidation reduction. The equivalent circuit for dynamic of the PEMFC is as in Fig. 1.

Open circuit voltage: The theoretical value of an open circuit voltage of a PEMFC is $1.2 \mathrm{~V}$ based on the Eq. 1 where $\Delta \bar{g}$ is the change in molar Gibbs free energy formation (Samosir et al., 2010) is. The value of the open circuit voltage is exact to an operation of the fuel cell under $100^{\circ} \mathrm{C}$. There will be a slight difference or equal to the open circuit voltage when the fuel cell operates in real

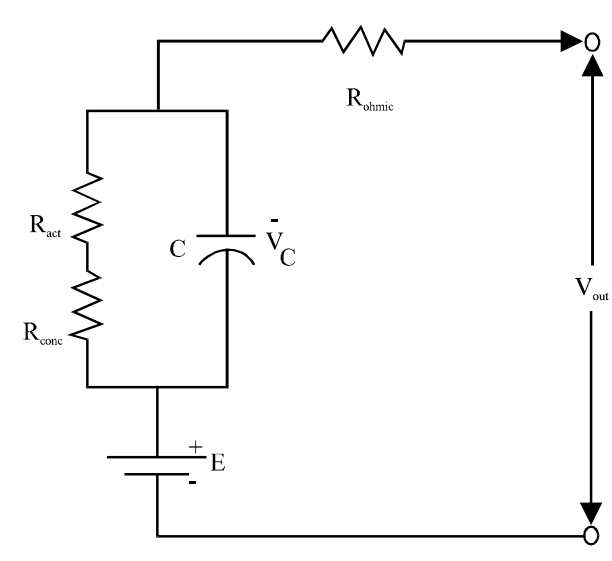

Fig. 1: the equivalent dynamic circuit of PEMFC

life where the value will be drop a little due to the temperature operation of the fuel cell lower than $100^{\circ} \mathrm{C}$ :

$$
E=\frac{-\Delta \bar{g} f}{2 F}
$$

Kinetics: Kinetics is the speed of reactions between hydrogen and oxygen in the system. The kinetics most affective towards the cell potential where it stands as a limit of the production. The Tafel slope of the output voltage against current density of the fuel cell is how the losses presented.

Kinetics can be increase by injecting the pressure of the input hydrogen to the fuel cell as in Eq. 2, A is the partial pressure, $\mathrm{F}$ is faradays constant, $\mathrm{R}$ is a gas constant and $\mathrm{E}_{\mathrm{r}}^{0}$ is the standard reversible potential:

$$
E_{r}=E_{r}^{0}+\frac{R T}{n F} \ln \left[\frac{\mathrm{AH}_{2} \cdot \mathrm{Ao}_{2}{ }^{1 / 2}}{\mathrm{AH}_{2} \mathrm{O}}\right]
$$

Steady-state: Steady state is a state where all the variables are constantly, even of ongoing process happening is going to change the state of the variables. It's a concept that is different from chemical equilibrium even both may create a situation where the concentration does not change but in equilibrium system the products transform into reactants at the same rate as reactants transform into products. There is no need for reaction to occur to develop a steady state and there is no limitation in steady state.

Therymodynamic: Dynamic is when the reaction of the reactants occurs which the results from the reaction produces energy in a form of heat and electron. Dynamic of fuel cell is after the consideration of the steady state 
which the hydrogen and oxygen started to react and produce electron, water and heat. The term thermodynamic is to indicate the production of heat from the reaction occurs after steady-state in dynamic.

Steady-state mathematical: Steady state is the main criteria that should be considered first for modelling PEMFC. The activation losses, concentration losses and the ohmic losses are the main losses that delivered practically from the fuel cell and can be observed through the steady state model. The modelling of steady state includes the stacks of equations by using mathematical blocks to be combined into a subsystem. The voltage drop of the steady state model was represented in the equation below where $\mathrm{n}$ is the gain of losses:

$$
\mathrm{V}_{\text {cell }}=\mathrm{E}+\mathrm{n}_{\text {act }}+\mathrm{n}_{\text {conc }}+\mathrm{n}_{\text {ohmic }}
$$

In Eq. $2, V_{\text {cell }}$ is the output voltage of the fuel cell in a single cell, $\mathrm{E}$ is the thermodynamic potential of the fuel cell, whereas $V_{\text {act, }} V$ conc $V$ onmis the activation, concentration and the Ohmic voltage. While in Eq. 3 shows the equation for the voltage gain of the fuel cell, whereas $n_{\text {act }}, n_{\text {conce }}, n_{\text {ohmic }}$ are the negative of activation, concentration and Ohmic voltage and the pressure of hydrogen is expressed in Eq. 4.

$$
\begin{gathered}
\mathrm{E}=1.229-0.8 \times 10^{-3}\left(\mathrm{~T}_{\text {cell }}-298.15\right)+ \\
4.31 \times 10^{-5}\left(\ln \mathrm{PH}_{2}+\frac{1}{2} \ln \mathrm{PO}_{2}\right) \\
\mathrm{PH}_{2}=\mathrm{PH}_{2} \mathrm{O}^{\text {sat }}\left[\exp \left(-\frac{1.6351}{\mathrm{~T}_{\text {cell }}{ }^{1.334}}\right) \frac{\mathrm{Pa}}{\mathrm{PH}_{2} \mathrm{O}^{\text {sat }}}-1\right]
\end{gathered}
$$

The mass transport losses and the resistance for the concentration on the surface of the electrode in the fuel cell is represented in Eq. 5 as the concentration losses in the mathematical model. The activation losses in the losses occur due to the resistance at the surface of the electrode in Eq. 6, the Ohmic losses occur during the transfer of protons expressed in Eq. 9:

$$
\begin{gathered}
\mathrm{n}_{\text {conc }}=B \ln \left(1-\frac{\mathrm{i}}{\mathrm{i}_{\text {lim }}}\right) \\
\mathrm{n}_{\text {act }}=-0.9514+3.12 \times 10^{-3} \mathrm{~T}_{\text {cell }}-1.87 \times 10^{-4} \mathrm{~T}_{\text {cell }} \operatorname{lni}+ \\
7.4 \times 10^{-5} \mathrm{~T}_{\text {cell }} \operatorname{lni}+7.4 \times 10^{-5} \mathrm{~T}_{\text {cell }} \ln \mathrm{C}_{02} \\
\mathrm{n}_{\text {ohmic }}=-\mathrm{iR}_{\text {int }}
\end{gathered}
$$

$$
\begin{gathered}
\mathrm{R}_{\text {int }}=1.605 \times 10^{-2}-3.5 \times 10^{-5} \mathrm{~T}_{\text {cell }}+8 \times 10^{-5} \mathrm{i} \\
\mathrm{T}_{\mathrm{c}}=\mathrm{T}_{\text {cell }}-273.15
\end{gathered}
$$

In Eq. 9, the $\mathrm{T}_{\text {cell }}$ is the lump temperature of the cell where the temperature is in Kelvin and expressed in Eq. 10 while in Eq. $7 \mathrm{~B}$ is a constant where the value is 0.016 and can be expressed in Eq. 11 where the $\mathrm{R}$ is the gas constant, $\mathrm{T}$ is the temperature in Kelvin, $\mathrm{n}$ is the number of mol and $\mathrm{F}$ is Faradays Law constant.

$$
\mathrm{B}=\frac{\mathrm{RT}}{\mathrm{nF}}
$$

The product of the reaction is the electron and water, which electron was sent to the cathode and the water produced at anode. The electron flowing through cathode will result in electrical energy that can provide energy to a vehicle that used fuel cell.

Dynamic mathematical: A dynamic model is a better understanding of the process involved in the fuel cell operation for both membrane level and the auxiliary subsystems (Lee and Cho, 2009). A coupled of a complex system which is fluid-solid-heat-electrochemistry that were considered as the process of the electrochemical reaction to occur. The charge double layer capacitance is the effect that causing the behavior of the fuel cell where the jumping of charge between two contacted surfaces (Azri et al., 2016). The jumping of charge happens in fuel cell during the reaction between the electrode and the ion in the electrolyte. The charge double layer capacitance is labelled as $V_{c}$ in the mathematical model as expressed in Eq. 12:

$$
\begin{aligned}
& \mathrm{V}_{\mathrm{c}}=\mathrm{V}_{\text {act } 0}+\mathrm{V}_{\text {conc }} \\
& \mathrm{R}_{\mathrm{c}}=\frac{\mathrm{V}_{\text {act } 0}+\mathrm{V}_{\text {conc }}}{\mathrm{i}} \\
& \frac{\mathrm{dV}_{\text {act }}}{\mathrm{dt}}=\frac{\mathrm{i}}{\mathrm{c}}-\frac{\mathrm{V}_{\text {act }}}{\mathrm{RcC}}
\end{aligned}
$$

In the Eq. 13 and 14, the $V_{\text {act }}$ is the dynamic activation losses of the PEMFC and the $\mathrm{V}_{\mathrm{act}} \mathrm{O}$ was taken from the steady-state model of the PEMFC. The $\mathrm{R}_{\mathrm{c}}$ in Eq. 13 is the internal impedance of the capacitor and known as capacitive reactance and can also be represented as $\mathrm{X}_{\mathrm{c}}$. Several factors such as heat from the electrochemical reaction where the heat loss to the surroundings, heat transfer between electrodes could affect the changing of 
temperature in the fuel cell. The rate of change for the activation voltage $\mathrm{V}_{\text {act }}$ over time is expressed in Eq. 15 . Equation 15 represents the differential equation of the thermodynamic model of the PEMFC where $C_{t}$ is the total thermal capacitance for all the volume or mass of fuel cell which is equal to $10 \mathrm{~J} / \mathrm{K}, \mathrm{H}$ is the total heat transfer coefficient for all fuel cell surfaces which is $10 \mathrm{~W} / \mathrm{K}, \mathrm{T}_{\mathrm{f}}$ is the environment temperature reference which is $303.15 \mathrm{~K}$ and $\mathrm{T}_{\text {cell }}$ is the lumped temperature of the fuel cell in Kelvin (Samosir et al., 2010).

$$
\mathrm{C}_{\mathrm{t}} \frac{\mathrm{dT}}{\mathrm{dt}}=\mathrm{i}\left(\mathrm{E}-\mathrm{V}_{\text {cell }}\right)-\mathrm{H}\left(\mathrm{T}_{\text {cell }}-\mathrm{T}_{\mathrm{f}}\right)
$$

Steady-state electrical: Steady-state is the first criteria to be considered first before the reaction of hydrogen and oxygen occurs in the system. Generally steady-state of electrical is meant by the flow of electric current in the circuit without having the voltage stacks and by just considering the losses. The electrical differs than the mathematical is that there is no temperature or heat consideration for the electrical.

The steady-state of the electrical is differs from the dynamic in a way of using the losses to produce the output. As mention that steady-state is a state where the state before reaction occurs in the system meant that there will be no generator used to produce the output of the steady-state. The behavior of CDL does not includes in steady-state electrical and only includes the OCV where the OCV of the steady-state is equal to $V_{\text {cell }}$ in Eq. 16.

$$
\begin{gathered}
\mathrm{V}_{\text {cell }}=\mathrm{E}-\left(\mathrm{V}_{\text {conc }}+\mathrm{V}_{\text {act }}+\mathrm{V}_{\text {ohmic }}\right) \\
\mathrm{V}_{\text {cell }}=\mathrm{E}+\mathrm{n}_{\text {act }}+\mathrm{n}_{\text {ohmic }}+\mathrm{n}_{\text {conc }}
\end{gathered}
$$

Dynamic electrical: The dynamic of the electrical model is using electrical component to implement the voltage drops, OCV and the CDL produce the output voltage, desired current and output power. The usage of ramp to set the slope of the output by using Eq. 18 to get the value of the slope where $y_{2}$ is the peak value for desired current, $\mathrm{y}_{1}$ is the initial desired current value, $\mathrm{x}_{2}$ peak value for output voltage and $x_{1}$ is the initial value of the initial output voltage. If there is no generator the output voltage, current and power will be in a form of straight lines (DC). The usage of the block ramp is to get the desired output by following the spec of horizon-500 PEMFC:

$$
\mathrm{m}=\frac{\mathrm{y}_{2}-\mathrm{y}_{1}}{\mathrm{x}_{2}-\mathrm{x}_{1}}
$$

Table 1: the specification of the horizon-500 PEMFC

\begin{tabular}{ll}
\hline Type of fuel cell & Proton exchange membrane \\
Number of cells & 36 \\
Rated power & $500(\mathrm{~W})$ \\
Rated voltage & $21.6(\mathrm{~V})$ \\
Rated current & $24 \mathrm{~A}$ \\
Efficiency & $40 \%(21.6(\mathrm{~V})$ \\
\hline
\end{tabular}

The value of the drops $n_{\text {ohm }}, n_{\text {act, }} n_{\text {conc }}$ are represented as a resistor $\left(\mathrm{R}_{\text {act }} \mathrm{R}_{\text {ohm }}, \mathrm{R}_{\text {conc }}\right)$ and connected in series. The $\mathrm{CDL}$ applied in the model by connecting a capacitor parallel with $R_{\text {act }}$ and $R_{\text {conc }}$. The OCV implemented by connecting a resistance as load $\left(\mathrm{R}_{\text {load }}\right)$ series with the $\mathrm{DC}$ supply. The output value and the resistance value are obtained by using basic ohm's Law equation.

Simulation model: The price of a real fuel cell in the market is high and it is harder to do maintenance due to less expertise in the field locally. Therefore, by modelling the mathematical and electrical of the PEMFC using Matlab/Simulink will help to understand the process and the working of the real-life fuel cell. The modeling of mathematical is to follow the specification of Horizon-500 and the electrical is to show that the working process can also be represents in electrical model. The specification for the Horizon-500 is as in Table 1.

Mathematical model: The mathematical model was modeled using Matlab/Simulink simulation software using equations and interprets in a form of mathematical blocks. The process of modeling started with modeling the steady-state and then followed by the dynamic model by following the spec of Horizon-500 PEMFC as in Table 1.

Steady-state mathematical: The first criteria to be consider on modelling the actual PEMFC model is the steady-state model where the model is a combination of subsystem that taken from equations from steady-state. The main losses that is activation, concentration and ohmic can be practically observe from through the steady-state model. The output voltage of the steady-state $V_{\text {cell }}$ can be represented from the fuel cell equivalent circuit (Azri et al., 2016). The voltage drop can be represented in a form of voltage gain (n) as in Eq. 19 and the reversible voltage (E) can be represented in Eq. 20.

$$
\begin{gathered}
\mathrm{V}_{\text {cell }}=\mathrm{E}+\mathrm{n}_{\text {act }}+\mathrm{n}_{\text {conc }}+\mathrm{n}_{\text {ohmic }} \\
\mathrm{E}=1.229-8.5 \times 10^{-4}\left(\mathrm{~T}_{\text {cell }}-298.15\right)+ \\
4.308 \times 10^{-5}\left(\ln \mathrm{P}_{\mathrm{H} 2}+\frac{1}{2} \ln \mathrm{P}_{\mathrm{O} 2}\right)
\end{gathered}
$$

In Figure 2 shows the subsystem of predicted thermodynamic voltage that implemented in Matlab/Simulink where the partial pressure of the two 


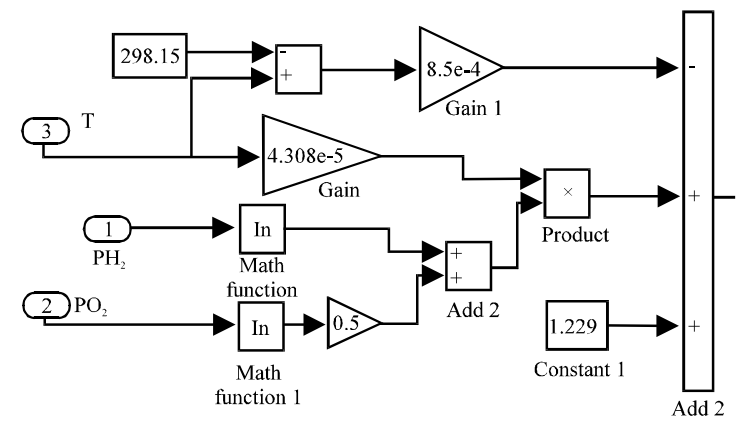

Fig. 2: tthe predicted thermodynamic voltage

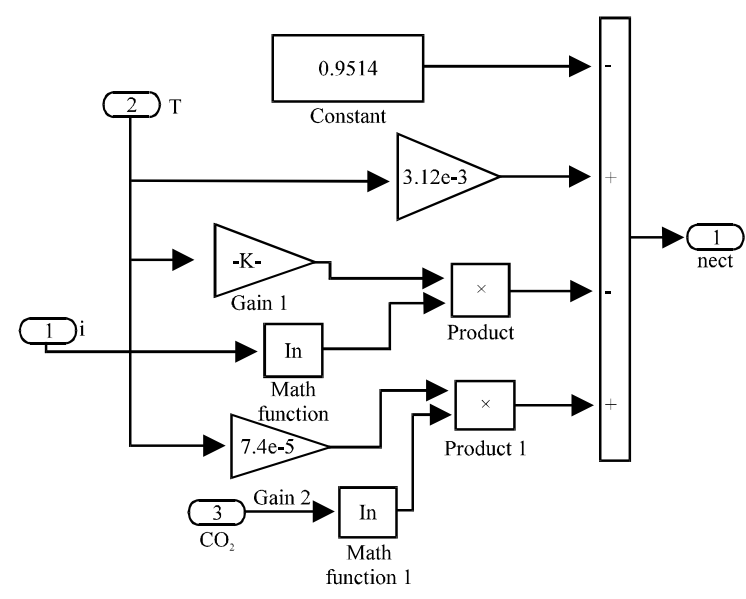

Fig. 3: The activation losses

input of the subsystem is the hydrogen and oxygen are an important factor for the thermodynamic voltage. The partial pressure of hydrogen and oxygen is expressed in Eq. 21 and 22:

$$
\begin{aligned}
& \mathrm{PH}_{2}=\frac{1}{2} \mathrm{PH}_{2} \mathrm{O}^{\text {sat }}\left[\exp \left(-\frac{1.6351}{\mathrm{Tcel}^{1.334}}\right) \frac{\mathrm{Pa}}{\mathrm{PH} 2 \mathrm{O}^{\text {sat }}}-1\right] \\
& \mathrm{PO}_{2}=\mathrm{PH}_{2} \mathrm{O}^{\text {sat }}\left[\exp \left(-\frac{4.1921}{\text { Tcell }^{1.334}}\right) \frac{\mathrm{Pa}}{\mathrm{PH}_{2} \mathrm{O}^{\text {sat }}}-1\right]
\end{aligned}
$$

The saturation pressure for water is expressed in Eq. 23 where $T_{c}$ is the actual temperature of the fuel cell and can be expressed in Eq. 10:

$$
\begin{aligned}
& \log _{10} \mathrm{PH}_{2} \mathrm{O}^{\text {sat }}=-2.18+2.95 \times 10^{-2} \mathrm{~T}_{\mathrm{e}}^{-} \\
& 9.18 \times 10^{-5} \mathrm{~T}_{\mathrm{c}}^{2}+1.44 \times 10^{-7} \mathrm{~T}_{\mathrm{c}}^{3}
\end{aligned}
$$

The relationship between voltage and gain of the three losses can be expressed in Eq. 16-17. The losses play important roles in the fuel cell system and in the output voltage against current. In the output voltage

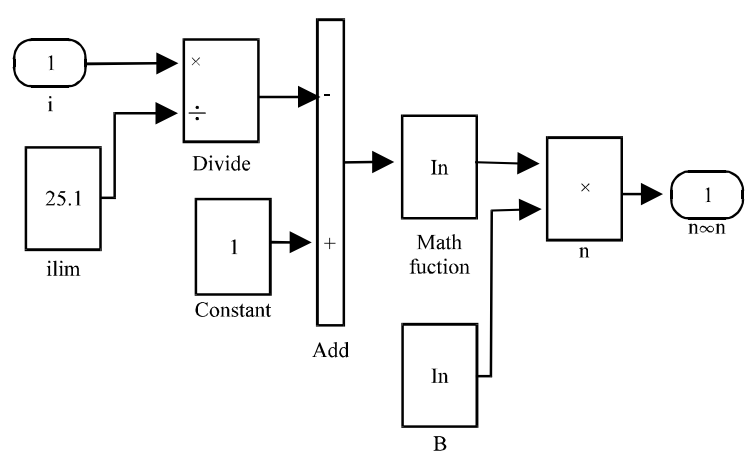

Fig. 4: The concentration losses

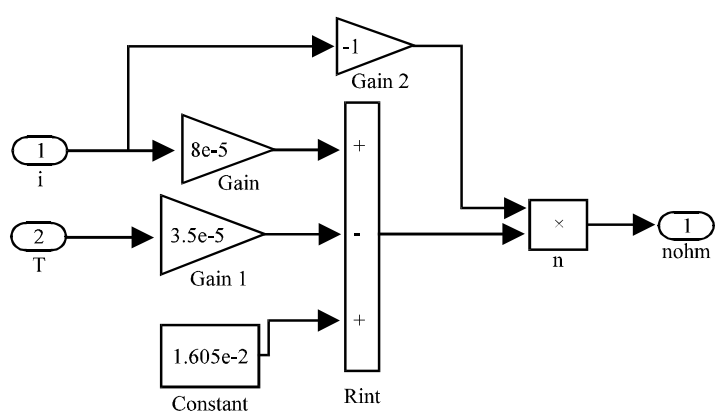

Fig. 5 The ohmic losses

curve is caused by the all three losses and the desired current. The activation losses are a losses caused by the resistance at the surface of the electrode. The configuration of the activation is implemented in Fig. 3. The concentration losses are due to the concentration on the surface of electrodes and the mass transport losses in the cell. The concentration losses can be expressed in Eq. 6. Figure 4 shows the concentration losses mathematical subsystem. The Ohmic losses is generally due to the process of transferring proton and electron from the oxidation reduction reaction. The ohmic losses is expressed in Eq. 6 and Fig. 5 shows the mathematical subsystem configuration of the Ohmic losses.

Dynamic mathematical model: The dynamic mathematical is a modeling of complex system that is considered as electrochemical reaction occur. The equation of CDL is labeled as $V_{c}$ to understand the dynamic electrical behavior of the system. Practically the reaction between the electrodes and the ions in the electrolyte has led CDL to occur in the system. The differential equation for the $\mathrm{CDL}$ is expressed to the fuel cell equivalent circuit from Eq. 27-29:

$$
\mathrm{V}_{\mathrm{c}}=\mathrm{V}_{\mathrm{act} 0}+\mathrm{V}_{\mathrm{conc}}
$$




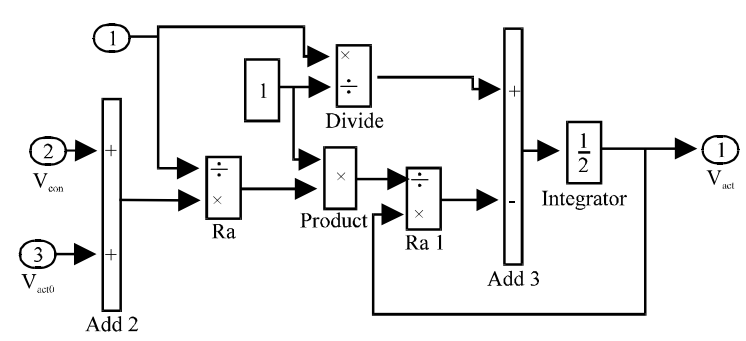

Fig. 6: The dynamic activation losses

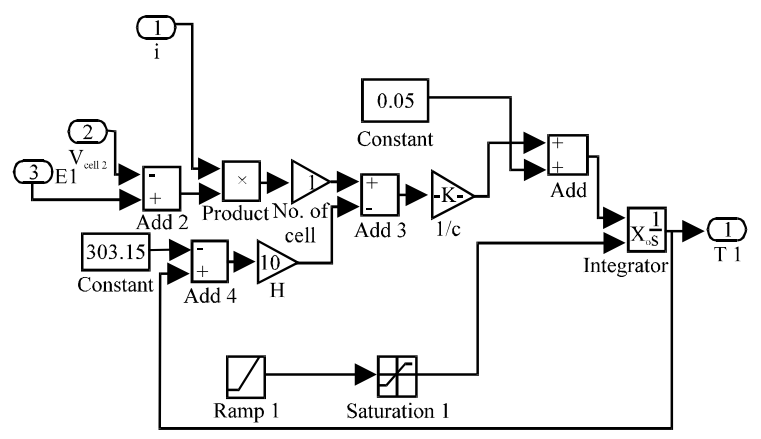

Fig. 7: The thermodynamic subsystem of PEMFC

$$
\begin{aligned}
& \mathrm{R}_{\mathrm{c}}=\frac{\mathrm{V}_{\text {act }}+\mathrm{V}_{\text {conc }}}{\mathrm{i}} \\
& \frac{\mathrm{dV}}{\mathrm{dt}}=\frac{\mathrm{i}}{\mathrm{C}}-\frac{\mathrm{V}_{\text {act }}}{\mathrm{R}_{\mathrm{c}} \mathrm{C}}
\end{aligned}
$$

Figure 6 shows the dynamic activation losses of the PEMFC where the $V_{\text {acto }}$ taken from the steady-state mathematical model. There are other factors that could affect the temperature of the fuel cell such as heat loss to surrounding, heat transfer between electrodes and the electrochemical reaction. The thermodynamic model of PEMFC can be expressed in Eq. 30 where $\mathrm{Ct}$ is the total thermal capacitance for the total volume or mass of fuel cell.

$$
C_{t} \frac{d T}{d t}=i\left(E-V_{\text {cell }}\right)-H\left(T_{\text {cell }}-T_{f}\right)
$$

Figure 7 shows the thermodynamic subsystem of the PEMFC where the reference temperature of the fuel cell is set at $303.15 \mathrm{~K}\left(30^{\circ} \mathrm{C}\right)$.

Electrical model of pemfc: The $\mathrm{R}_{\text {act }}$ was used to implement the activation losses which are important in low currents and indicates the amount of energy requires by the cell to start the circulation of the electron and break the chemical bonding at both anode and cathode. Thus, it will result in drop of voltage at low current densities in both anode and cathode. In dynamic, the activation losses are always dominated in the cathode and the relationship between the activation losses can be described in Eq. 6 where $\mathrm{A}$ is a constant (Al-Baghdadi and Al-Janabi, 2005).

The $\mathrm{R}_{\text {conc }}$ reflects to the mass transportation in the fuel cell by the process of convection and diffusion where the convection is the transport of species by bulk movement of a fluid and the diffusion refers to the transport of species due to concentration. The mass transport in the electrode is mainly dominated by the diffusion. The concentration become higher when the current of the cell is higher (Correa et al., 2005).

The $R_{\text {olm }}$ is acting as the internal resistance of the fuel cell. The usage of the resistor is to create the resistance of the polymeric membrane to create the Ohmic losses towards the proton circulation and the resistance of the collector current and the electrodes. The oxidation reduction reaction must be constantly fed by the reactants and the product which is water must be correctly removed. Equation 33 were used to find the concentration voltage where $\mathrm{m}$ and $\mathrm{n}$ are empirical parameters:

$$
\begin{gathered}
\mathrm{V}_{\mathrm{ohm}}=\mathrm{i}\left(\mathrm{R}_{\mathrm{ohm}}\right) \\
\mathrm{V}_{\text {act }}=\mathrm{A} \operatorname{In}\left(\frac{\mathrm{i}}{10}\right) \\
\mathrm{V}_{\text {conc }}=\mathrm{m} \exp \left(\mathrm{ni}_{\text {conc }}\right)
\end{gathered}
$$

Steady-state electrical: The implementation for the steady-state model using Matlab/Simulink is to leave capacitor as an open circuit so that there is no application of $\mathrm{CDL}$ in the circuit. The steady-state model did not have the generator since it only considers the current demand of the cell before proceeding to dynamic model. The output of steady-state is a straight line (DC) for the desired current, output voltage and the output power. The $\mathrm{R}_{\text {ohm }}, \mathrm{R}_{\text {act }}$ and $\mathrm{R}_{\text {otm }}$ are connected in series by following the cell voltage Eq. 34 for steady-state. The current is limited to $25 \mathrm{~A}$ to follow the specification of the Horizon-500 PEM fuel cell:

$$
\begin{aligned}
\mathrm{V}_{\text {cell }} & =\mathrm{E}-\mathrm{i} \mathrm{R}_{\mathrm{ohm}}-\mathrm{i} \mathrm{R}_{\text {act }}-\mathrm{iR} \text { conc } \\
\mathrm{R} & =\frac{\text { Voltage gain }}{\text { Desired current }}
\end{aligned}
$$

Dynamic electrical model: The implementation of charge double layer capacitance is used by connecting capacitor parallel with $\mathrm{R}_{\text {act }}$ and $\mathrm{R}_{\text {conc }}$ and the input $\mathrm{DC}$ supply is to implement the open circuit voltage. The usage of the saturation in the output of current is to limit the current to $25 \mathrm{~A}$ because of the desired current of the Horizon-500. January 2, 2019The circuit in Fig. 8 and 9 shows the 


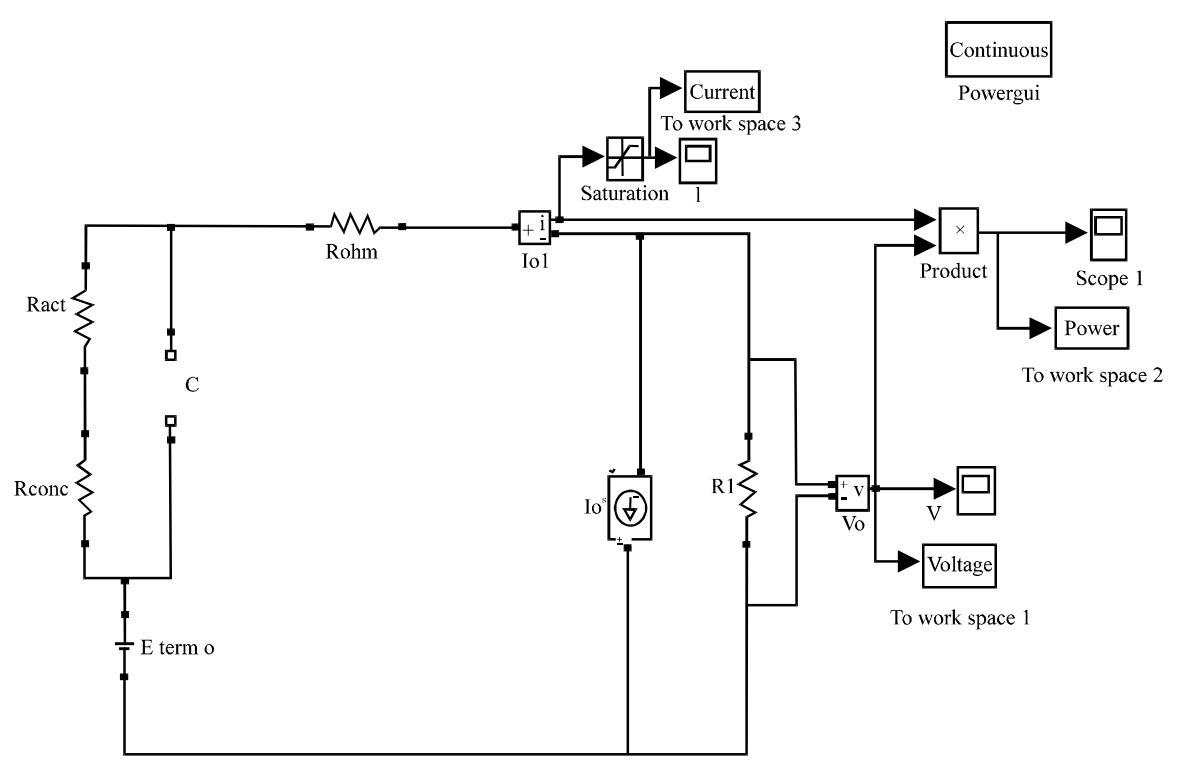

Fig. 8: The steady-state electrical model

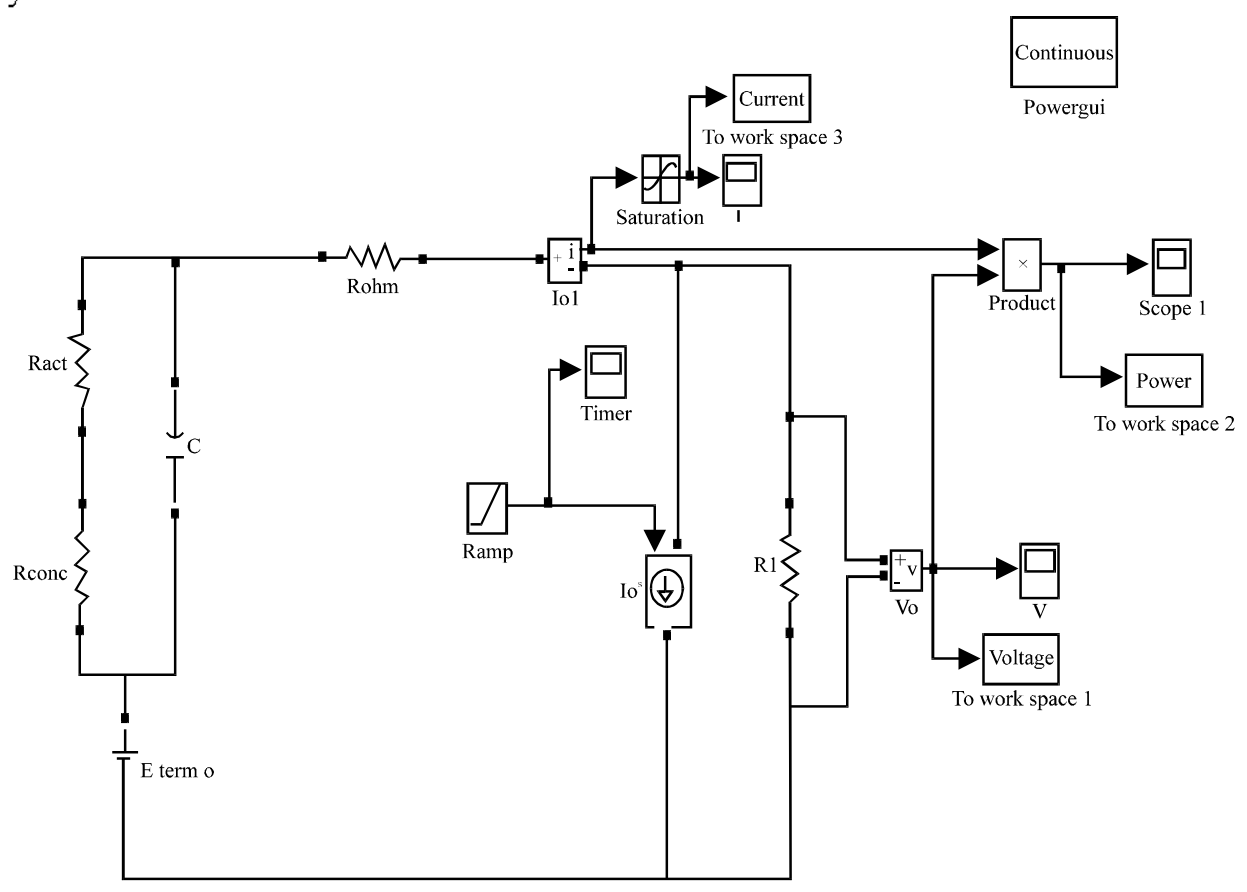

Fig. 9 The dynamic electrical model

dynamic electrical model of the PEM fuel cell where the usage of ramp to set the slope of the output just like in the mathematical model. The implementation of the voltage drop is represented using resistor. Using kirchhoff's law to get the charge Double Layer Capacitance (CDL) of the dynamic electrical model as in Eq. 34:

$$
\mathrm{E}-\mathrm{i} \mathrm{R}_{\text {act }}-\mathrm{i} \mathrm{R}_{\text {conc }}-\mathrm{i} \mathrm{R}_{\mathrm{ohm}}-\mathrm{V}_{\mathrm{c}}=0
$$

$$
\mathrm{V}_{\mathrm{c}}=\mathrm{E}+\mathrm{i} \mathrm{R}_{\text {act }}+\mathrm{iR}_{\text {conc }}+\mathrm{iR} \text { ohm }
$$

\section{RESULTS AND DISCUSSION}

The results of both model obtained from the simulation done in Matlab/Simulink Simulation Software. The output taken out is the output voltage delivered and the output power. The variation of temperature and 


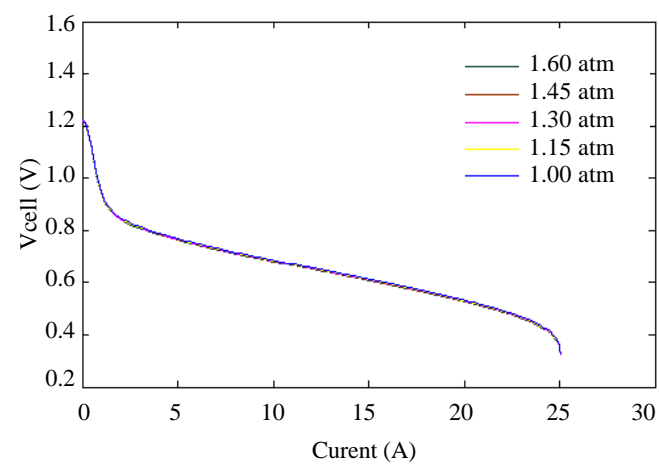

Fig. 10: The output voltage for varying pressure of hdrogen mathematical model

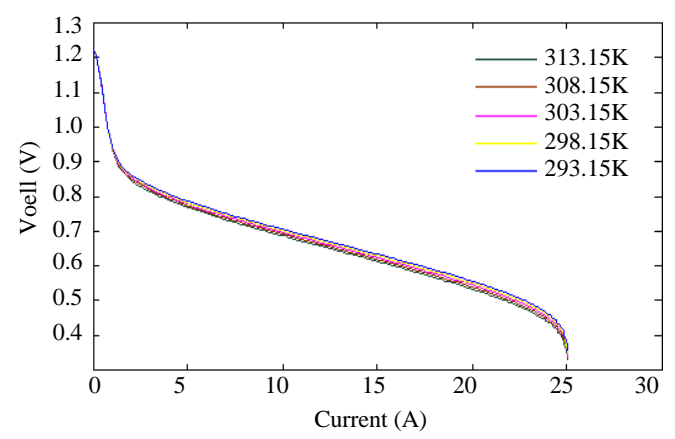

Fig. 11: Tthe output voltage for varying the cell temperature mathematical model

hydrogen pressure were used to test the certainty of the model and to verify the parameters used in both model.

Varying the hydrogen pressure and temperature of mathematical model: The purpose of varying the pressure of hydrogen and the temperature of the fuel cell is to verify the parameter used in the modeling process. For the process of varying the pressure of hydrogen, the value used is $(1.00,1.15,1.30,1.45,1.60 \mathrm{~atm})$ and the pressure of oxygen stays at $1.00 \mathrm{~atm}$ which represents the air standard pressure. By varying the input pressure could affect the output voltage where the increasing of pressure will lead to a higher output voltage. The output voltage of varying the input pressure of hydrogen is shown in Fig. 10.

On the other hand, varying the temperature of the cell also will affect the output voltage of the fuel cell. As been stated that the higher output produced will lead to a higher temperature of the fuel cell. By varying the temperature from $293.15,298.15,303.15,308.15$ and 313.15 $\mathrm{K}$ to analyze the output voltage of the fuel cell. The output voltage is shown in Fig. 9 and it is proven that a higher voltage output lead to a higher cell temperature Fig. 11.

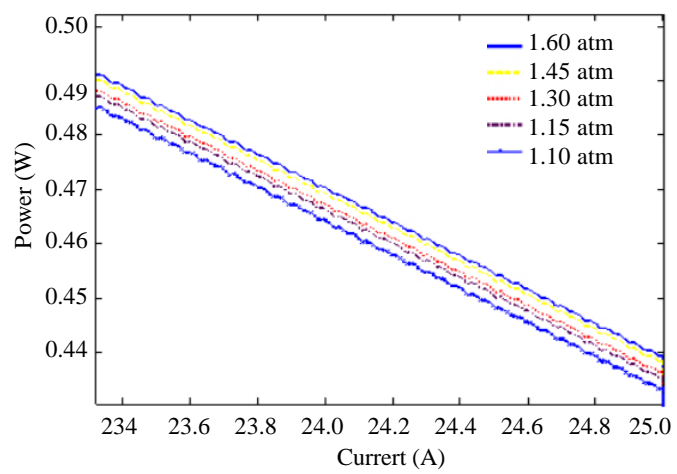

Fig. 12: The output voltage for varying the input pressure of hydrogen electrical model

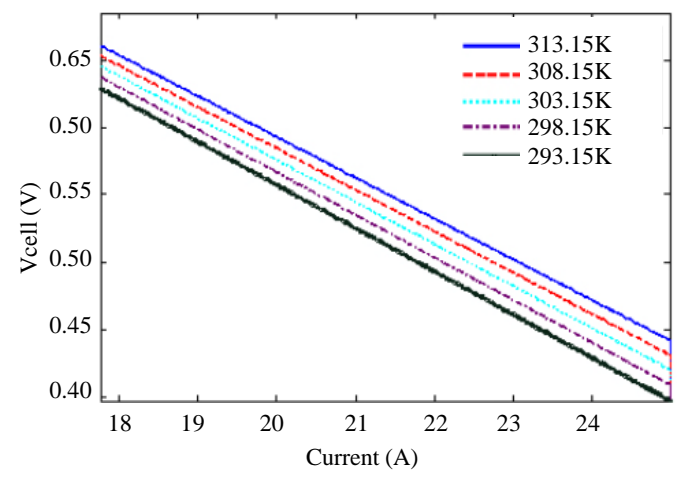

Fig. 13: The output voltage for varying the cell temperature electrical model

Varying the hydrogen pressure and temperature of electrical model: By using the value of voltage drops from the mathematical and convert it into form of resistance to be use in the electrical model. The steps of varying the output voltage based on the increase of hydrogen pressure and the cell temperature. By analyzing the output for both method, the parameter can be optimizing and verified. The output voltage after varying the input pressure of hydrogen is shown in Fig. 12 and the output voltage after varying the cell temperature is shown in Fig. 13. The approach is to prove that by increasing the input pressure of hydrogen and the cell temperature will increase the output voltage produce.

Choose the parameter used to run the mathematical and electrical model: After simulating the electrical and mathematical model using different pressure and temperature the parameter was verified by using $1.45 \mathrm{~atm}$ and $303.15 \mathrm{~K}$ due to the ideal pressure and cell temperature for the fuel cell. The output for electrical and mathematical model is as shown in Fig. 12-15.

Figure 12 shows the varying of the hydrogen pressure of the cell which will affect the output voltage of 


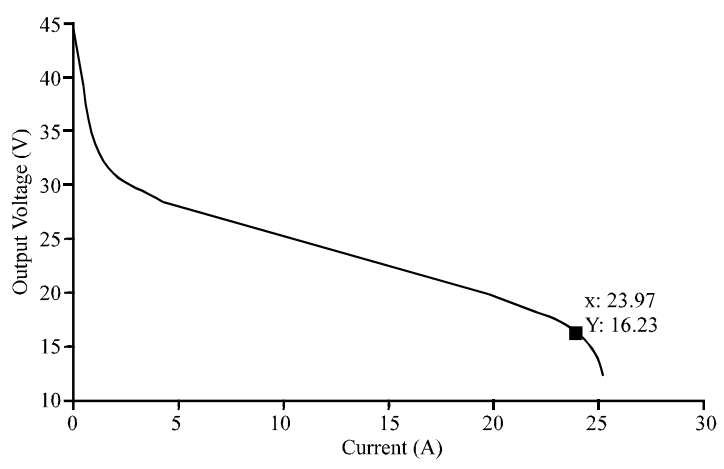

Fig. 14: The output voltage against current of the mathematical model

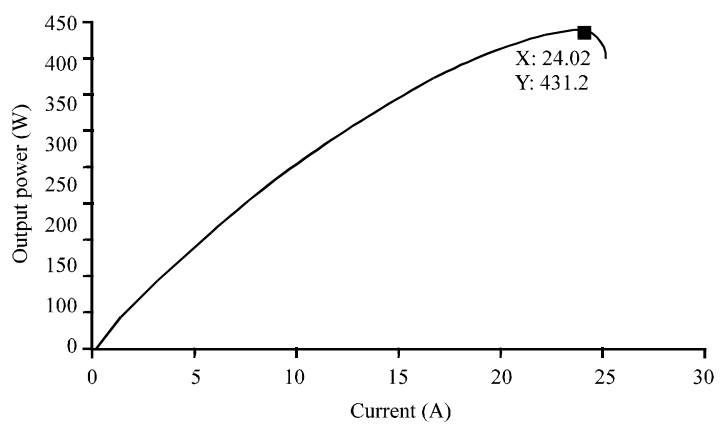

Fig. 15: The output power against current of the fuel cell for mathematical model

the fuel cell. As been stated that the higher output produced will lead to a higher temperature the higher pressure leads to a higher voltage produced. By varying the hydrogen pressure from 1.10, 1.15, 1.30a, 1.45 and 1.60 atm to analyze the output voltage of the fuel cell by changing the resistor value based on losses in the electrical model.

Figure 13 is the varying of the cell temperature which affect the output voltage of the fuel cell. As been stated that the higher output produced will lead to a higher temperature of the fuel cell. By varying the temperature from $293.15,298.15,303.15,308.15$ and $313.15 \mathrm{~K}$ to analyze the output voltage of the fuel cell by changing the value of resistor based on losses in the electrical model.

Figure 14 shows the voltage agaisnt current waveform (Tafel slope) of the mathematical model of the PEMFC using Matlab/Simulink where the output waveform curve is as the same as the horizon-500 waveform of voltage vs current.

The value of the stack voltage is may be differing with the cell voltage times with the number of cell due to the effect from the input hydrogen pressure that causing the output voltage to be higher.

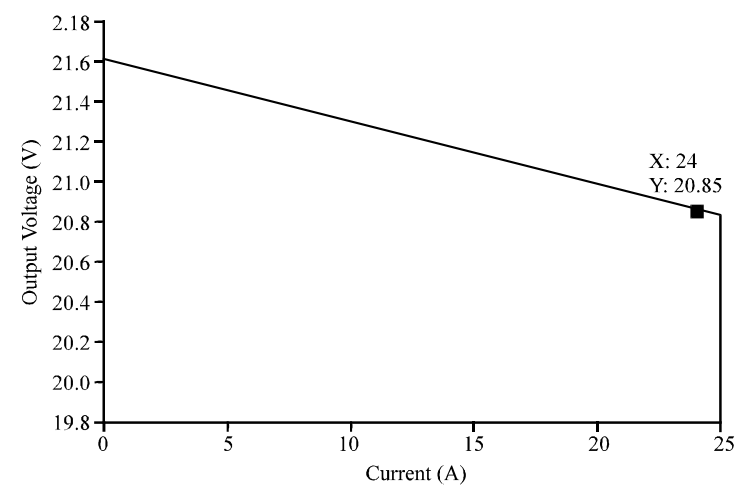

Fig. 16: The delivered voltage against current for the electrical model

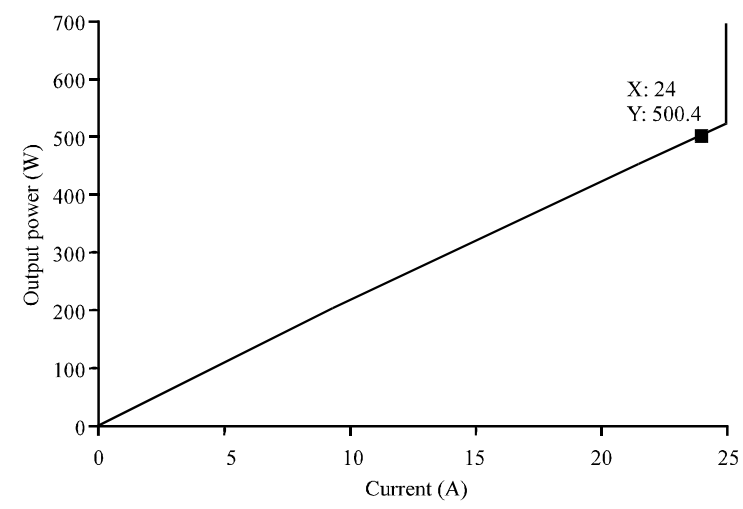

Fig. 17: The output power against current for the electrical model

Figure 15 shows the output power against current taken from the mathematical model of the PEMFC where the power intersect current at $24 \mathrm{~A}$ is $431.2 \mathrm{~W}$. The waveform also represents the power delivered by the fuel cell where it should be linear in increasing of the current demand and the drop at the end was caused by the current limiter $\left(i_{\mathrm{lim}}\right)$ in Eq. 6.

Figure 16 shows the voltage against current of the electrical model by using Matlab/Simulink where the output waveform shows the model fulfilled the requirement as the efficiency is $39.10 \%$ at $24 \mathrm{~A}$ compared to Horizon-500 PEMFC efficiency $40 \%$ at $24 \mathrm{~A}$.

Figure 17 shows the output power delivered by the electrical model where it has fulfilled the specification of the Horizon-500 which is500 W@24 A. The power increased linearly with the current demand of the PEMFC.

Comparison between mathematical and electrical model: Table 2 comparison of efficiency, losses, efficiency, stack voltage, rated power and current densities between 
Table 2: comparison of outputs for both model

\begin{tabular}{lll}
\hline Aspects & Mathematical Model & Electrical Model \\
\hline Time response (sec) & 25 & 22.5 \\
$\mathrm{R}_{\text {act }}(\Omega)$ & $-0.9514+3.12 \times 10^{-3}$ & $\mathrm{~V}_{\text {act }} / \mathrm{i}$ \\
& $\mathrm{T}_{\text {cell }}-1.87 \times 10-4$ & \\
& $\mathrm{~T}_{\text {cell }} \ln \mathrm{I}+7.4 \times 10^{5}$ & \\
& $\mathrm{~T}_{\text {cell }} \ln \mathrm{C}_{\mathrm{O} 2}$ & \\
$\mathrm{R}_{\text {ohm }}(\Omega)$ & $-\mathrm{i} \mathrm{R}_{\text {int }}$ & $\mathrm{V} \Omega / \mathrm{i}$ \\
$\mathrm{R}_{\text {conc }}(\Omega)$ & $\mathrm{B} \ln \left(1-\mathrm{i} / \mathrm{i}_{\text {lim }}\right)$ & $\mathrm{V}_{\text {conc }} / \mathrm{i}$ \\
Stack voltage $(\mathrm{V})$ & 16.23 & 20.85 \\
Current density $\left(\mathrm{A} / \mathrm{cm}^{2}\right)$ & 25 & 25 \\
$\mathrm{~V}_{\text {cell }}(\mathrm{V})$ & 0.4381 & 0.5792 \\
Rated power $(\mathrm{W})$ & 431.2 & 500 \\
Efficiency $(\%)$ & 30.43 & 39.10 \\
Number of cells & 36 & 36 \\
\hline
\end{tabular}

mathematical and electrical model. By comparing the output of both mathematical and electrical model, the factor that affecting the performance of the model can be identify. The output was then recorded and then analyzed by using equations used to determine the factor affecting the output for both model.

The value of the mathematical model is lower compared to electrical model due to the effects of temperature as stated in Eq. 2 and 3. The temperature plays an important role on the performance of the model where it is depending on the period of operation for the system where the longer or shorter the period of the operation will affect the value of the voltage drop losses. The electrical produced a higher output compared to mathematical due to the electrical were modeled with no temperature consideration towards the model.

The value for $V_{\text {cell }}$ for mathematical will not be equal to the stack voltage because of input hydrogen pressure that affect the value of stack for rated power and output voltage as stated in Eq. 3 (Azri et al., 2016). A higher input pressure for hydrogen led to a higher output voltage. An enormous difference in a higher pressure towards the stack output. The input hydrogen will only affect the stack output and does not affect the drop of the system. The higher the input pressure of hydrogen in the system, the higher value of the output stack voltage.

Both of the model was simulating in a duration of $50 \mathrm{~s}$. The time response for the model to reach $25 \mathrm{~A} / \mathrm{cm}^{2}$. The electrical model is faster compared with the mathematical model according to the waveform of the current where the current in electrical model reached $25 \mathrm{~A} / \mathrm{cm}^{2}$ in $22.5 \mathrm{sec}$ compared to mathematical model who take $25 \mathrm{sec}$ to reach $25 \mathrm{~A} / \mathrm{cm}^{2}$.

The efficiency of the fuel cell was measured using Eq. 35. The specification for the Horizon-500 is $40 \%$ at $21.6 \mathrm{~V}$. The mathematical model efficiency is $9.57 \%$ less compared to the Horizon-500 specification while the electrical model efficiency is $0.9 \%$ less then the $40 \%$ rated efficiency at $21.6 \mathrm{~V}$. The efficiency of both model has satisfied the requirement for an optimization of the parameter used in the model. The model can be improved by using intelligent temperature controller to control the temperature of the system so that the efficiency of the output produced is higher or near to the specification of Horizon-500 (Azri et al., 2016).

$$
\eta_{\mathrm{e}}=\left(0.675 \mathrm{~V}_{\text {cell }}\right) \times 100 \%
$$

\section{CONCLUSION}

The price of a fuel cell in the market is expensive and by modeling a mathematical model and electrical model to imitate the fuel cell system to show that it can be represented in other way to understand the behavior. The results obtained from analysis of varying the input hydrogen pressure and the cell temperature has proved that the cell temperature will affect the voltage drop losses of the system and the input pressure will only affect the stack output voltage of the model. The effect on the output of the model is due to the temperature which has led to a $9.57 \%$ less for mathematics and $0.9 \%$ less for the electricity compared to the Horizon-500 specification and the parameter used for the model is verified by comparing with the specification of the Horizon-500. Thus, the parameter used in both model is optimized and acceptable by comparing the efficiency of the system with the Horizon-500. The model can be complied to imitate the working process of the Horizon-500 PEMFC.

\section{ACKNOWLEDGEMENT}

We are honored for the UTeM scholarship for authors that has opens up new opportunity to establish in the electrical engineering power electronic field (LRGS/2014/FKE/TK01/02/R00004).

\section{REFERENCES}

Al-Baghdadi, M. A.S. and H.A.S. Al-Janabi, 2005. Optimization study of proton exchange membrane fuel cell performance. Turkish J. Eng. Environ. Sci., 29: 235-240.

As1, S.M.S., S. Rowshanzamir and M.H. Eikani, 2010. Modelling and simulation of the steady-state and dynamic behaviour of a PEM fuel cell. Energy, 35: 1633-1646.

Azri, M., A.N.A. Mubin, Z. Ibrahim, A.B.D.R. Nasrudin and S.R.S. Raihan, 2016. Mathematical modelling for Proton Exchange Membrane Fuel Cell (PEMFC). J. Theor. Appl. Inf. Technol., 86: 409-419.

Bizon, N., 2010. On tracking robustness in adaptive extremum seeking control of the fuel cell power plants. Applied Energy, 87: 3115-3130. 
Correa, J.M., F.A. Farret, V.A. Popov and M.G. Simoes, 2005. Sensitivity analysis of the modeling parameters used in simulation of proton exchange membrane fuel cells. IEEE. Trans. Energy Convers., 20: $211-218$.

Cownden, R., M. Nahon and M.A. Rosen, 2001. Modelling and analysis of a solid polymer fuel cell system for transportation applications. Intl. J. Hydrogen Energy, 26: 61 5-623.

Friede, W., S. Rael and B. Davat, 2004. Mathematical model and characterization of the transient behavior of a PEM fuel cell. IEEE. Trans. Power Electron., 19: 1234-1241.

Gao, F., B. Blunier, M.G. Simoes and A. Miraoui, 2011. PEM fuel cell stack modeling for real-time emulation in hardware-in-the-loop applications. IEEE. Trans. Energy Convers., 26: 184-194.

Grasser, F. and A.C. Rufer, 2007. An analytical, controloriented state space model for a PEM fuel cell system. Proceedings of the International Conference on Power Conversion ConferenceNagoya PCC'07, April 2-5, 2007, IEEE, Nagoya, Japan, pp: 441-447.

Hamelin, J., K. Agbossou, A. Laperriere, F. Laurencelle and T.K. Bose, 2001. Dynamic behavior of a PEM fuel cell stack for stationary applications. Intl. J. Hydrogen Energy, 26: 625-629.

Hinaje, M., S. Rael, P. Noiying, D.A. Nguyen and B. Davat, 2012. An equivalent electrical circuit model of proton exchange membrane fuel cells based on mathematical modelling. Energies, 5: 2724-2744.

Kunusch, C., P. Puleston and M. Mayosky, 2012. Sliding-Mode Control of PEM Fuel Cells. Springer, Berlin, Germany, ISBN:978-1-4471-2430-3, Pages: 176.

Laminie, J. and A. Dicks, 2003. Fuel Cell Systems Explained. 2nd Edn., John Wiley \& Sons, Chichester, England, UK., ISBN:9780470848579, Pages: 406.

Le, A.D. and B. Zhou, 2008. A general model of proton exchange membrane fuel cell. J. Power Sources, 182: 197-222.

Lee, D.J. and L. Wang, 2007. Dynamic and steady-state performance of PEM fuel cells under various loading conditions. Proceedings of the IEEE International Conference on Power Engineering Society General Meeting, June 24-28, 2007, IEEE, Tampa, Florida, USA., pp: 1-8.
Lee, J.M. and B.H. Cho, 2009. A dynamic model of a PEM fuel cell system. Proceedings of the 24th Annual IEEE Conference on Applied Power Electronics Conference and Exposition APEC09, February 15-19, 2009, IEEE, Washington, DC, USA., ISBN:978-1-42442811-3, pp: $720-724$.

Mann, R.F., J.C. Amphlett, M.A. Hooper, H.M. Jensen and B.A. Peppley et al., 2000. Development and application of a generalised steady-state electrochemical model for a PEM fuel cell. J. Power Sour., 86: 173-180.

Pukrushpan, J.T., H. Peng and A.G. Stefanopoulou, 2002. Simulation and analysis of transient fuel cell system performance based on a dynamic reactant flow model. Proceedings of the ASME 2002 International Mechanical Engineering Congress and Exposition on Dynamic Systems and Control, November 17-22, 2002, ASME, New Orleans, Louisiana, USA, ISBN:07918-3629-0, pp: 637-648.

Samosir, A.S., M. Anwari and A.H.M. Yatim, 2010. A simple PEM fuel cell emulator using electrical circuit model. Proceedings of the IEEE International Conference on IPEC, October 27-29, 2010, IEEE, Singapore, ISBN:978-1-4244-7399-1, pp: 881-885.

Thomas, S., S.C. Lee, A.K. Sahu and S. Park, 2014. Online health monitoring of a fuel cell using total harmonic distortion analysis. Intl. J. Hydrogen Energy, 39: 4558-4565.

Ural, Z. and M. T. Gencoglu, 2010. Mathematical models of PEM fuel cells. Proceedings of the 5th International Conference on Ege Energy Symposium and Exhibition (IEESE-5) Vol. 5, June 27-30, 2010, Pamukkale University, Denizli, Turkey, pp: 1-8.

Xiao, Y. and K. Agbossou, 2009.. Interface design and software development for PEM fuel cell modeling based on Matlab/Simulink environment. Proceedings of the WRI World Congress on Software Engineering WCSE'09 Vol. 4, May 19-21, 2009, IEEE, Xiamen, China, ISBN:978-0-7695-3570-8, pp: 318-322.

Xue, X., J. Tang, A. Smirnova, R. England and N. Sammes, 2004. System level lumped-parameter dynamic modeling of PEM fuel cell. J. Power Sources, 133: 188204.

Yuvarajan, S. and D. Yu, 2004. Characteristics and modelling of PEM fuel cells. Proceedings of the 2004 International Symposium on Circuits and Systems ISCAS'04 Vol. 5, May 23-26, 2004, IEEE, Vancouver, BC, Canada, pp: V-880-V-883. 